e-mail: waldekrapior@gmail.com

\title{
Poszerzone metody. Siedem kwestii dla badań kultury zwiększających zakres naszej wolności ${ }^{1}$
}

\begin{abstract}
\section{Extended Methods: Seven Issues for Culture Studies That Increase Our Freedom}

The author presents a model of the research approach that increases our freedom. What issues should a researcher consider if he/she wants to study culture in the $21^{\text {st }}$ Century technological, social and economic circumstances? The author distinguishes seven issues that a researcher guided by the broader concept of culture, one that defines culture according to Raymond Williams as a "specific way of life" should consider. These issues are: (1) research is an interaction between scientists and study participants; (2) research can democratize the culture field; (3) research can be a cultural animation; (4) cooperation with artists, activists, educators, etc. is important; (5) there are many regulators of human behavior; (6) researcher has to answer a question what important social goals the study supports; (7) ethical aspects of social phenomena have to be taken into consideration. The article is a voice in a discussion of whether research methods only describe social reality or help to create it.

Keywords: culture, participation in culture, educational turn in culture, mix-methods, democratization, qualitative and quantitative research, freedom

Słowa kluczowe: poszerzona koncepcja kultury, uczestnictwo w kulturze, zwrot edukacyjny w kulturze, metodologia badań kultury, demokratyzacja pola kultury

Podczas seminarium w Instytucie Socjologii UAM w 2014 roku, dotyczącego projektu „Praktyki kulturalne Polaków”, który prezentował obraz uczestnictwa Polaków w kulturze alternatywny wobec badań prowadzonych przez GUS, Marek

\footnotetext{
1 Tekst powstał w ramach grantu Narodowego Centrum Nauki nr 2015/19/N/ HS6/01682.
} 
Krajewski - jeden z autorów badan - wspominał o tym, że kwestionariusz użyty w badaniu jest bardzo długi (potencjalnie uciążliwy dla badanych). Jaka jest inna możliwość, dopytywał Krajewski? Nie da się zrobić badań, mówił, z wykorzystaniem dzienników wizualnych na próbie ogólnopolskiej. Pytanie to jest dla mnie ważne, ponieważ w latach 2010-2014 zrealizowałem badania publiczności Festiwalu Malta z użyciem dzienników wizualnych ${ }^{2}$. Jednocześnie, zarówno Krajewski, jak i zespół realizujący badania na Malcie definiowali uczestnictwo w kulturze szeroko, nie tyle jako uczęszczanie do instytucji kultury, ile jako „oddziaływanie pewnego elementu (jednostki, grupy, ale też przedmiotu, organizmu żywego itp.) na sposób powiązania ze sobą części konstytuujących określoną zbiorowość" [Krajewski 2013: 50]. Szeroka koncepcja kultury nie zawęża jej do dóbr i produktów wytwarzanych przez instytucje kultury ${ }^{3}$. Nie jest nią również tylko sztuka. Kultura jest po prostu „specyficznym sposobem życia" [Williams 1985: 90; Bennett 2005]. W ostatnich latach coraz więcej instytucji kultury ${ }^{4}$ za cel własnych działań obiera nie tyle zbliżenie swoich uczestników do ideału „człowieka kulturalnego” (chodzącego do teatru, czytającego książki, dobrze ułożonego), ile próbuje zbudować zbiorowość, nawiązać relacje, spotkać z sobą ludzi pochodzących z różnych klas społecznych, upodmiotowić wszystkich członków wspólnoty, z którą pracują. Działania te wpisują się w poszerzoną koncepcję kultury ${ }^{5}$. Czy można znaleźć cechy wspólne badań kwestionariuszowych i badań z wykorzystaniem dzienników wizualnych i na ich podstawie przedstawić metodologię adekwatną do zmian w kulturze i poszerzonej koncepcji kultury?

$\mathrm{W}$ artykule przedstawię model podejścia badawczego, który praktykuję, nie tylko zresztą ja; dostrzegłem podobne podejście u innych badaczy ${ }^{6}$. Przedstawiona tu

2 Na temat tych badań zob. http://badanieteatru.pl/ [odczyt: 24.02.2020] oraz film socjologiczny zrealizowany w 2010 roku „Malta -wymiana podwójna”, https://vimeo.com/32982533 [odczyt: 24.02.2020].

${ }^{3}$ Instytucje kultury przestają być dziś potrzebne jednostkom do tego, aby pośredniczyły w dostępie do kultury jako miejsca, w którym się z niej korzysta [Krajewski 2017]. Co więcej, w kreowaniu hierarchii wartości dóbr kultury i jej twórców instytucje kultury konkurują dziś z blogerami, influencerami, mediami społecznościowymi, niezależnymi galeriami, sąsiedzkim kinami podwórkowymi czy hip-hopowym żargonem. Instytucje kultury przestały mieć relatywny monopol na określanie, co należy zobaczyć, przeczytać, obejrzeć i gdzie pójść. Instytucje kultury zmieniają dziś strategie działania, poszerzają ofertę kultury, adaptują się do rzeczywistości poprzez zapraszanie do siebie różne kategorie osób, wchodząc z nimi w dialog.

${ }^{4}$ Mam tu na myśli takie instytucje, jak (by wymienić tylko pięć): Generator Malta w Poznaniu, Centrum Praktyk Edukacyjnych w Poznaniu, Pracownia Badań i Innowacji Społecznych „Stocznia”, Małopolski Instytut Kultury - Kraków, Instytut Kultury Miejskiej w Gdańsku.

${ }^{5}$ „Tym, co spaja, bardzo zróżnicowane, jak pokażę, formy poszerzania jest dążenie do uznania za kulturowe tego, co nie było w ten sposób traktowane, a więc w istocie próba redefiniowania statusu i umiejscowienia objętych tymi działaniami aspektów rzeczywistości” [Krajewski 2017: 33]. Na temat poszerzonej koncepcji kultury zob. Obracht-Prondzyński, Zbieranek 2017.

${ }^{6}$ Model ten nie jest propozycją dedukcyjną, lecz wziął swój początek z mojej praktyki badawczej oraz z procesu badawczego: porównywania metodologii zastosowanych w różnych badaniach kultury. Projekty, które porównywałem ze sobą znajdują się w Archiwum Wizualnym, www.archiwumwizualne.pl [odczyt: 24.02.2020] oraz na stronie www.badanieteatru.pl [odczyt: 24.02.2020]; był to również 
propozycja podejścia badawczego jest głosem w dyskusji nad nowymi metodami badań kultury, które nie tylko poszerzałyby naszą wiedzę o niej, ale też pole kultury, a więc byłyby przedsięwzięciem obywatelskim [Chajbos, Rapior, Szymańska-Palaczyk 2014; Rakowski 2015; Sikora 2015]. Artykuł jest wstępem do dyskusji i pracy nad możliwością obywatelskiej metodologii badań kultury. Taka dyskusja jest dziś niezmiernie potrzebna, ponieważ, z jednej strony, wielu badaczy w naukach społecznych nie traktuje takich metod jak badanie w działaniu i action research [Skórzyńska 2017], performance as research [Kosiński, Rapior 2018], art-based-research [Sormani, Carbone, Gisler 2018] za metody naukowe [por. Law 2004; Lury, Wakeford 2012]. Z drugiej strony, w ostatnim czasie pojawiło się wiele danych o tym, że replikowalność badań przeprowadzanych w bardzo kontrolowanych warunkach, powtarza się tylko, gdy badania replikacyjne przeprowadzono w tym samym laboratorium [Chambers 2017]. Jak powiedział Dawid Wiener: „Kontekst badacza i kontekst laboratorium zaczyna wpływać na efekty i rzekomą obiektywność wiedzy, która jest tam reprodukowana" [O czym mówi Sean? 2019: 256]. Dyskusja nad statusem metod w badaniach społecznych już trwa [Allard 2018]. Badania nad kulturą mogą wnieść w tę debatę kilka nowych spostrzeżeń, dlatego że kultura spaja ludzi z sobą, tworzy więzi społeczne, buduje relacje i dostarcza narzędzi do tego, abyśmy mogli wspólnie żyć. Sposoby uwzględnienia przez badaczy kultury w swych badaniach społecznotwórczego charakteru kultury, mogą być istotne w dyskusji nad metodami i metodologiami nauk społecznych.

Celem tego artykułu nie jest porównywanie metod badawczych, wskazywanie, które lepiej lub gorzej sprawdzają się w badaniu kultury, lecz analiza relatywnie nowego zjawiska w badaniach kultury: poszerzania koncepcji kultury i metod badawczych przez badaczy kultury w Polsce ${ }^{7}$. Co wynika z tych „nowych” badań? Nasuwa się odpowiedź, że demokratyzowanie pola kultury. Podobne zadanie postawili sobie autorzy raportu „Praktyki kulturalne Polaków”. Ich celem była zmiana kwestionariusza GUS do badania uczestnictwa w kulturze ${ }^{8}$. Marek Krajewski tłumaczył, że „tradycyjne badania uczestnictwa, polegające na rejestrowaniu wielkości konsumpcji dóbr kulturowych upowszechnianych przez rozmaite instytucje, nie są zdolne do uchwycenia bardzo wielu form tego procesu, ponieważ formy te nie są traktowane jako przejaw uczestnictwa w kulturze" [Krajewski 2013: 45] ${ }^{9}$. Aby uchwycić

projekt „Praktyki kulturalne Polaków”, „Animacja/edukacja. Możliwości i ograniczenia edukacji i animacji kulturowej w Polsce”, „Nowe praktyki kulturowe Polaków”.

7 Zob. przyp. 5.

${ }^{8}$ Barbara Fatyga pisała we „Wprowadzeniu” do raportu: „Roczniki i badania GUS poświęcone tematyce kultury były powszechnie uważane za najgorzej i najbardziej anachronicznie opracowane wydawnictwa z zakresu statystyki publicznej. Ich podstawę stanowiła bowiem wizja kultury zakorzeniona w podejściach teoretycznych i metodologicznych oraz wizjach polityki kulturalnej z pierwszej połowy XX wieku” [Drozdowski et al. 2014: 11].

$9 \mathrm{~W}$ innym miejscu ten sam autor pisał, że tradycyjne badanie uczestnictwa „wycina z pola widzenia badacza emocje, zmysły, doświadczenia cielesne jako istotne elementy uczestniczenia w kulturze, a tym samym usuwa w cień cały szereg praktyk kulturowych, których celem i sensem nie jest 
wielość form uczestnictwa kultury autorzy badań „Praktyki kulturalne Polaków” zastosowali bardzo tradycyjną w socjologii technikę badawczą - kwestionariusz. Jednakże skonstruowali pytania kwestionariuszowe tak, aby technika ta pozwoliła zidentyfikować różne przejawy uczestnictwa Polaków w kulturze. Analizując raport „Praktyki kulturalne Polaków”"10, a przede wszystkim własną praktykę badawczą (badania z wykorzystaniem dzienników wizualnych oraz warsztatów socjologiczno-teatrologicznych „Tworzenie kultury” $i$ „Młodzi i teatr” ${ }^{11}$ oraz badania na pograniczu sztuki i nauki „Moralność milcząca”" ${ }^{2}$ ), próbuję zdać relację z tego, co jest istotne w badaniach, w których kultury nie redukuje się do konsumpcji dóbr bądź odbioru dzieł sztuki. Jakie kwestie powinien rozważyć badacz, który chciałby badać kulturę w sposób przystający do zmian w kulturze, jakie obserwujemy w XXI wieku [Lury, Wakeford 2012]?

Wyróżniłem siedem kwestii, które badacz kultury kierujący się poszerzoną koncepcją kultury powinien rozważyć. Nie ma tu miejsca, aby każdą z nich rozwijać i szczegółowo uzasadniać, tym bardziej wchodzić w polemikę z badaczami, którzy nie podzielają mojej perspektywy. Skupię się na ich opisie.

\section{Badanie jest interakcją}

Pierwszą kwestią jest uznanie, że badanie to interakcja. W największym skrócie można powiedzieć, że interakcyjny wymiar badania polega na tym, iż w trakcie przeprowadzania wywiadu, eksperymentu albo kwestionariusza „coś dajemy i coś zabieramy" uczestnikom badań. Traktowanie metod badawczych jak narzędzi do

emitowanie i dekodowanie znaczeń” [Krajewski 2013: 45]; oraz że tradycyjne badania uczestnictwa „W odniesieniu do konkretnego przykładu, rejestrują zmniejszenie się liczby książek przeczytanych przez Polaków, ale nie są w stanie zarejestrować przeobrażeń, jakim wraz z pojawieniem się telefonów komórkowych, sieci, e-booków uległy praktyki związane z czytaniem, tego, jak w ostatnich dekadach przeobraziły się relacje między wydawcami, księgarzami i czytelnikami, a także między tymi ostatnimi a autorami" [Krajewski 2013: 48].

${ }^{10}$ Ostatni rozdział tego raportu to transkrypcja dyskusji jego autorów nad metodologicznymi i teoretycznymi problemami, które napotkali podczas realizacji badań; czytelnik ma dostęp do tego, jak bronili i krytykowali oni in situ własne podejście badawcze

${ }^{11}$ W 2011 roku zrealizowaliśmy projekt pt. „Tworzenie kultury. Badania uczestnictwa w kulturze”, który wsparło Ministerstwo Kultury i Dziedzictwa Narodowego (program „Obserwatorium Kultury"). Celem badań było sprawdzenie niestandardowych narzędzi jakościowego badania kultury (m.in. dzienniki wizualne, foto-spacer, foto-głos, gra wideo, warsztaty teatrologiczne). W 2013 roku, dzięki ponownemu wsparciu MKiDN, badaliśmy szanse i bariery stawiane młodym ludziom w wieku 16-19 lat, w uczestnictwie w kulturze teatralnej, zob. http://badanieteatru.pl/.

${ }_{12}$ Projekt zrealizowany w ramach grantu Narodowego Centrum Nauki nr 2015/19/N/ HS6/01682. Celem tego projektu nie była analiza uczestnictwa kultury, niemniej materiał empiryczny wytworzony przy współpracy naukowców i artystów w trakcie jego realizacji można z powodzeniem interpretować w kontekście teorii odbiorczych i uczestnictwa w kulturze. 
tworzenia interakcji, a nie kontekstu dla zdobywania informacji, kieruje uwage badacza na to, jak przebiega ta interakcja. Mówiąc inczaej, badacz zaczyna stawiać sobie pytanie, czy badanie jest równoprawną wymianą między nim, badanymi i odbiorcami badań.

Według Herberta Blumera, twórcy interakcjonizmu symbolicznego, interakcja symboliczna „obejmuje interpretacje, czyli stwierdzenie znaczenia działań lub uwag innej osoby oraz definicję, czyli przekazanie wskazówek innej osobie, jak zamierza się działać” [Blumer 2006: 265]. Interakcjonizm symboliczny powstał w latach trzydziestych XX wieku jako alternatywa dla trzech innych podejść badania ludzkiego zachowania: teorii instynktu, teorii bodźca-reakcji (S-R) i teorii kultury. $\mathrm{W}$ każdym z tych trzech ujęć człowiek jest traktowany jak bierny organizm: albo kierowany instynktem, albo warunkowany przez środowisko, albo determinowany przez „kulturę”, czyli zewnętrzną wobec osoby strukturę kształtującą jego zachowania. Interakcjonizm symboliczny podkreślał, że ludzie są refleksyjni, a nie pasywni.

Dziś nawet nauki społeczne, dla których fizyka jest wzorem do naśladowania ${ }^{13}$, uznają, że „życie społeczne jest dynamiczne”, „porządek społeczny wyłania się z interakcji” a „ludzie są refleksyjni” [Markovsky, Diks 2013: 27-28]. Jednakże stwierdzenie, które tu omawiam - badanie jest interakcją - nie odnosi się jedynie do brania pod uwagę, jako własności ludzkiego zachowania, tego, że ludzie, w przeciwieństwie do atomów i cząsteczek, są świadomi siebie i interakcji z innymi. Sformułowanie „badanie jest interakcją” oznacza przede wszystkim, że badacz powinien traktować samo badanie jako dynamiczny proces interakcyjny. Aby zilustrować, co mam na myśli, przedstawię trzy przykłady.

Pierwszym z nich jest wywiad badawczy. Jean-Claude Kaufmann [2010] podkreśla, że zaangażowanie badacza jest kluczowe do zrozumienia znaczeń, jakie rozmówca nadaje zjawiskom, osobom, grupom, rzeczom, o które pyta. Prowadzący wywiad, nawet gdy próbuje wyeliminować wszelkie swoje wpływy, oddziałuje na rozmowę i rozmówcę. Pełen rezerwy badacz, pisał francuski socjolog, udający, że nie ma ani uczuć, ani myśli, wywołuje u osoby badanej „specyficzną postawę polegającą na unikaniu nadmiernego zaangażowania" [Kaufmann 2010: 28]. Co więcej, wywiad należy dostosować nie tylko do osoby badanej i sytuacji badania ${ }^{14}$, ale też do kontekstu kulturowego. Na przykład typowy chiński rozmówca ma tendencję do szukania właściwych odpowiedzi na zadanie pytanie i chce przejść do następnego pytania, gdy na pierwsze została udzielona odpowiedź [Brinkmann 2016]. Taka postawa łamie przyjęty przez wielu zachodnich badaczy społecznych pewnik, że w wywiadzie jakościowym nie ma „właściwych” bądź „,niewłaściwych” odpowiedzi, że rozmówca jest traktowany jako „ekspert codzienności”, który snuje swoją opowieść. Chińczycy nie mają w swej kulturze zwyczaju wypowiadania się publicznie

\footnotetext{
${ }^{13}$ Kierują się one tzw. modelem poznania fizyki.

${ }^{14}$ Przykładem jest prowadzenie wywiadu z dziećmi.
} 
i opowiadania historii swojego życia nieznanej osobie. Na Zachodzie natomiast żyjemy w „społeczeństwie wywiadów” [Atkinson, Silverman 1997], w którym każdy $z$ nas jest zapoznawany przez mass media ze sposobem uczestniczenia w wywiadzie. Słowem wywiad to interakcja, w której pojawiają się wszystkie elementy procesu interakcyjnego - interpretacja, zogniskowanie uwagi rozmówców na siebie, kulturowe konwencje [Goffman 2006; 2008].

Również badania eksperymentalne są interakcją. Na przykład słynne eksperymenty nad posłuszeństwem Stanleya Milgrama, zostały przedstawione przez niego, jako czysta sytuacja „bodźca i reakcji”. Badany (grający rolę nauczyciela) otrzymuje polecenie, aby karał osobę za ścianą (grającego rolę ucznia aktora, choć badany nie wie, że jest to aktor). Karą są impulsy elektryczne - badany sądzi, że są one realne, podczas gdy w rzeczywistości aktor za ścianą jedynie odgrywa ból nimi wywołany. W miarę postępu eksperymentu pomocnik eksperymentatora prosi, aby badany kontynuował eksperyment i zadawał coraz silniejsze wstrząsy, pomimo wyraźnych oznak bólu, choć odgrywanych, dobiegających zza ściany. Najnowsze badania pokazały, że Milgram stworzył machinę manipulacyjną, która wymusiła na badanych posłuszeństwo [Perry 2013]. Jego badania powiedziały nam dużo o tym, jak można aktywnie mobilizować jednostki do tego, aby zrobiły to, czego chcemy [Haslam, Reicher 2012]. Milgram wykorzystał swoją wiedzę naukowca społecznego, do tego, aby pokierować interakcją między badanym, pomocnikiem eksperymentatora i aktorem za ścianą tak, aby badani byli posłuszni; nie przejął się również tym, co wydarzyło się z badanymi po wyjściu z laboratorium ${ }^{15}$. Tego błędu nie popełnił zespół Dariusza Dolińskiego [Doliński, Grzyb 2017], który przeprowadził badania replikacyjne w paradygmacie Milgrama. Zespół Dolińskiego rozmawiał z badanymi po zakończeniu eksperymentu, a w książce podsumowującej badania zamieszczone są zanonimizowane wypowiedzi badanych. Nie tylko to, co dzieje się w laboratorium, tworzy sytuację badawczą, ważna jest też sama interakcja między badanymi i badaczami przed wejściem do i po wyjściu z laboratorium. Traktowanie badanych inaczej niż tylko jak przedmiot badania (nawet przy zachowaniu wszelkich procedur etycznych danej dyscypliny), ale jak ludzi, którzy mogą być ciekawi badania, w którym wzięli udział, którzy mają jakieś motywacje, dlaczego przyszli do laboratorium, którzy po swojemu interpretują zdarzenie, w którym uczestniczyli, jest zwróceniem uwagi na to, że badanie jest interakcją.

Stwierdzenie „badanie jest interakcją” oznacza również, że wiedza zdobyta podczas badań demokratyzuje pole kultury, co zilustruję fragmentem raportu „Praktyki kulturalne Polaków”. Rafał Drozdowski zauważył, że przeprowadzając badania kwestionariuszowe, coś dajemy i coś zabieramy naszym respondentom. Drozdowski pytał: Czy ta wymiana jest równoprawna? Krajewski tak odpowiedział na to pytanie:

${ }^{15}$ Wielu badanych zastanawiało się nad eksperymentem, rozmawiało o nim z bliskimi, próbowało się uspokoić. 
Zwracasz [Rafał - W.R.] bowiem uwagę na to, że badanie powinno być interakcją, wymianą: że my powinniśmy zwrotnie w trakcie tych badań coś respondentom dawać. Wydaje mi się, że ten cel przez to badanie zostaje osiągnięty: efektem tych badań powinna być moim zdaniem jeżeli uda nam się taką dyskusję wywołać - zmiana sposobu mówienia o kulturze, zmiana sposobu myślenia o niej. A więc ta przemiana, o której piszesz - ona następuje, ponieważ my wysyłamy dość istotny sygnał, mający na celu demokratyzowanie myślenia o kulturze; wyjęcie myślenia o kulturze z oświeceniowego sposobu jej pojmowania, w którym jest ona ograniczona do kilku zaledwie praktyk, będących przedmiotem oddziaływania instytucji. A więc pomimo tego, że ten kwestionariusz jest rozległy, pomimo tego, że odpowiadanie na zawarte w nim pytania przynosi dyskomfort, to wymiana, która następuje z naszymi respondentami, polega na stopniowym - m.in. za pośrednictwem naszych badań - demokratyzowaniu tego pola. Wydaje mi się, że nasi respondenci są albo będą beneficjentami tego procesu [Drozdowski et al. 2014: 406].

Barbara Fatyga natomiast w raporcie „Praktyki kulturalne Polaków” podkreśla, że bardzo ważny jest proces szkolenia osób przeprowadzających wywiad kwestionariuszowy. Przyjęcie do wiadomości, że badanie jest interakcją oznacza po prostu profesjonalne podejście do badań. Dobrze przeszkolony ankieter będzie zadawał pytania tak, aby respondent je zrozumiał, będzie umiał zmotywować badanych do skupienia uwagi na kwestionariuszu ${ }^{16}$. Odpowiedź Krajewskiego wskazuje na kolejną kwestię metodologii pasującej do poszerzonego pola kultury - demokratyzację.

\section{Emancypacja i demokratyzacja}

Metody badawcze mogą służyć do demokratyzowania pola kultury, co nie oznacza, że badacz nie przestaje stosować kryteriów naukowych (np. dążenia do prawdy, rekonstrukcji faktów, budowania wiedzy obiektywnej), lecz że sytuacja badania sama w sobie ma potencjał demokratyczny. Na przykład poprzez dobór pytań i sposób ich zadawania badacz może pokazać badanemu, że praktyki, które być może przez niego są traktowane jako nieistotne, są godne uwagi badawczej. Krajewski, we fragmencie zacytowanym w poprzedniej części artykułu, wspominał, że demokratyzacja pola kultury polega na tym, iż badania przyczyniają się do zmiany myślenia o kulturze. Wiedza naukowa ${ }^{17}$ ma duży wpływ na to, co i jak robimy w życiu codziennym,

16 Warto zwrócić uwagę, że wysunięcie na pierwszy plan tego, że badanie jest interakcją, prowadzi do przyjrzenia się edukacji uniwersyteckiej. Kaufmann pisał: „Prawdę mówiąc w większości podręczników panuje wokół nich zgoda. I jedno, i drugie ma własnych specjalistów i własne techniki, które łączą się we względnie spójną całość, jaką jest bezosobowa i zestandaryzowana koncepcja wywiadu" [2010: 28].

${ }_{17}$ Pomimo iż słyszymy wciąż, że szczepionki są szkodliwe albo że smugi chemiczne (tzw. chemtrails) istnieją. 
a także jaką politykę prowadzą rządy państw [Collins 2018]. By lepiej zilustrować tezę o emancypacyjnym i demokratycznym charakterze badań kultury, odniosę się do debaty pt. „Kultura i przyszłość”, która odbyła się 10 września 2017 roku w poznańskiej Scenie Roboczej.

W debacie wzięli udział Elżbieta Korolczuk, Przemysław Czapliński, Michał Merczyński, Franciszek Sterczewski; moderatorem był Edwin Bendyk. Uczestniczyłem w debacie w roli widza. Rozmawialiśmy o polityce kulturalnej, o przeciwstawieniu się radykalnym zwrotom na polskiej scenie publicznej, o tym, jak zachęcić do uczestnictwa w kulturze instytucjonalnej osoby, które nie wykazują zainteresowania instytucjami kultury. W pewnym momencie jedna z osób z publiczności powiedziała: „Wychodzi na to, że należy kulturę podzielić na dwie części. Kulturę wysoką serwować dla elit, a kulturę niską dla mas. Jeśli chce się robić festiwal z kulturą wysoką, na przykład teatrem, to trzeba pewnie zaproponować masom jakieś proste spektakle uliczne, festyn lub koncert disco-polo". Wypowiedź ta uruchomiła falę komentarzy. Również zdecydowałem się zabrać głos. Opowiedziałem o badaniach, które przeprowadziliśmy podczas Festiwalu Malta oraz w teatrach i domach kultury w Wielkopolsce w ramach projektu „Tworzenie kultury” i „Młodzi i teatr”.

W Scenie Roboczej mówiłem o warsztatach socjologiczno-teatrologicznych. Starałem się pokazać, że myślenie opozycjami elity-masa, kultura wysoka-kultura niska, jest błędne. Owszem, istnieje wiele analiz wskazujących, że kultura w Polsce funkcjonuje zgodnie z podziałem, o którym wspomniał mężczyzna z publiczności ${ }^{18}$. Jednakże diagnoza nie powinna prowadzić do tego, że zaczynamy myśleć według podziałów, które ona ukazuje; diagnoza ma raczej pokazać stan faktyczny, by móc o nim wspólnie dyskutować i kształtować go za pomocą polityki kulturalnej ${ }^{19}$.

${ }_{18}$ Przemysław Czapliński tak opisał obie „kultury”: „Ani w pierwszej, ani w drugiej kulturze prawomocnej nie mieści się wytwarzanie realnych warunków sprzyjających zwiększaniu uczestnictwa w kulturze. Pierwszy projekt usiłował zawstydzić klasę średnią i poprzez wstyd popchnąć do aktywności. Wypracowany w ten sposób snobizm działał krótko i nie zostawił po sobie żadnych trwałych obyczajów - chodzenia do kin i teatrów, wypożyczania książek z bibliotek, uczestniczenia w spotkaniach z twórcami, samodzielnego muzykowania czy «teatrowania». Drugi projekt zatwierdza właśnie owo niechodzenie, nieuczestniczenie, niezwiedzanie. Kieruje, bowiem ludzi nie ku kulturze, jako sferze wzajemności, lecz jako sferze obowiązku patriotycznego. Zachętą do uczestnictwa w kulturze ma się stać duma z polskości i polskiej tradycji. Oznacza to jednak, że twórcy kultury tracą prawo do mówienia czegoś, co wykracza poza tradycjonalistyczny konsensus” [Czapliński 2017: 91].

${ }^{19}$ Myślenie o kulturze w Polsce za pomocą dwóch „kultur” („niskiej” i „wysokiej”) byłoby procesem reprodukowania tego podziału. Czapliński pisał: „Język wspólny Polaków coraz bardziej się kurczy, a im bardziej się kurczy, tym bardziej dzieli" [2017: 78]. Zmiana myślenia o kulturze jest niezbędna, aby wspierać proces jej demokratyzacji, czyli zwiększenia zakresu naszych praw i wolności, które nie prowadziłyby do przeobrażenia wspólnoty w szereg ekskluzywnych klubów i „światów-baniek”, „w których każdy z nas żyje wprawdzie po swojemu, ale wyłącznie wśród podobnych do siebie" [Krajewski 2013: 53]. Warto zaznaczyć, że poszerzenie pola kultury, a także nowe propozycje konceptualizacji kultury i w niej uczestnictwa, nie są wytworem języka, lecz spontanicznych i oddolnych zmian kulturowych. Język, jego bogactwo albo ubogość, pozwalają nam dostrzec praktyki, które przez 
Warsztaty socjologiczno-teatrologiczne, o których mówiłem podczas debaty w Scenie Roboczej, były formą wywiadu grupowego i techniką, która wpisuje się w strategię:

- rozwoju publiczności, czyli dotarcia do nowych grup odbiorców oraz zwiększenia wiedzy na temat publiczności ${ }^{20}$;

- polityki kulturalnej, czyli demokratyzowania odbioru kultury instytucjonalnej przez widzów rzadko uczęszczających do teatru;

- festiwalu teatralnego, czyli zwiększenia zainteresowania wydarzeniami teatralnymi;

- badawczą, a więc zrozumienia tego, jak widzowie doświadczają dzieł sztuki.

Do teatru - na spektakle w ramach Festiwalu Malta - zaprosiliśmy osoby, które deklarowały, że odwiedzają teatr sporadycznie. Mieliśmy więc przeważnie do czynienia z osobami, które w teatrze bywają dość rzadko i dla których kontakt $\mathrm{z}$ teatrem jest raczej wynikiem przypadku lub splotu okoliczności (czyjeś zaproszenie lub zachęta), jeśli zaś jest własną decyzją, to podejmowaną z przekonaniem, że spełnia się w ten sposób jakiś wymóg związany z uczestnictwem w „kulturze wysokiej”, a więc, że podejmuje się działanie niecodzienne, odświętne, wyjątkowe. Osoby te tworzyły sześcio-ośmioosobowe grupy. Każda z grup uczestniczyła dwa razy $\mathrm{w}$ dwóch przedstawieniach, a następnie spotykała się z badaczami podczas warsztatu. Na przykład grupa A szła do teatru w poniedziałek, a we wtorek uczestniczyła w warsztacie, następnie w czwartek wybrała się na kolejne dwa spektakle, a w piątek uczestniczyła w warsztacie. Staraliśmy się, aby wśród tych czterech spektakli znajdowały się zarówno te uchodzące za "klasyczne” (czwarta ściana, tradycyjny podział scena-widownia), jak i te uchodzące za "trudne”, „hermetyczne”, „niezrozumiałe” (interaktywne, postdramatyczne, multimedialne). Jak sobie z nimi radzą? Czy rzeczywiście częstą reakcją na spektakle „hermetyczne” jest odrzucenie i zniechęcenie, czy jednak nieprofesjonalni widzowie podejmują jakiś wysiłek interpretacyjny?

Aby odpowiedzieć na te pytania, nie trzeba sięgać do treści rozmów toczonych w ramach warsztatów - wystarczy spojrzeć na ich przebieg. Widzowie żywiołowo dyskutowali o spektaklach, które widzieli. Często po zakończeniu warsztatów - trwały one zwykle około dwóch godzin - uczestnicy spontanicznie klaskali w podziękowaniu za to, że mogli wziąć udział w badaniu; dziękowali nam, socjologowi i teatrologowi (za każdym razem dwie osoby prowadziły warsztat); pytały, czy będziemy w przyszłości organizować podobne spotkania. Jeden z najważniejszych wniosków z badań brzmi: Wystarczy, że pozwoli się tak zwanym masom (by nawiązać do słów

oficjalny dyskurs, m.in. zarządzania kulturą, przemysłu kulturowego, sektorów kultury, segmentacji publiczności, są niedostrzegane.

20 Takie podejście do rozwoju publiczności stosuje berliński Theater Ballhaus Naunynstrasse albo drezdeński Bürgerbühne; badacze wykorzystujący technikę rozmów z widzami, tacy jak Anja Mølle Lindelof i Louise Ejgod Hansen z Danii czy Rebecca Scollen z Australii. 
mężczyzny w Scenie Roboczej), mówiąc inaczej, nieprofesjonalnemu widzowi, swobodnie mówić, a także z zainteresowaniem słuchać go i wchodzić z nim w dyskusję, by dostrzec, że tak zwany zwykły widz jest w stanie doświadczać sztuki wysokiej.

Wniosek ten sugeruje, że stwierdzenie „teatr dla elit, festyn dla mas” (by znów przywołać słowa mężczyzny wypowiedziane w Scenie Roboczej) nie jest prawdą, choć w sensie statystycznym, teatr jest sztuką elitarną. Tomasz Szlendak sugeruje, że przedstawienia teatralne tworzone są głównie dla ludzi wykształconych, wykonujących zawody „inteligenckie”. „Do teatru chodzi ponad $60 \%$ studentów i osób pracujących w zawodach wymagających wyższego wykształcenia oraz ponad połowa osób z wykształceniem wyższym - pojawia się klarowna odpowiedź dla kogo wystawiane są sztuki" ${ }^{21}$ [Drozdowski et al. 2014: 161]. Widz niewykształcony nawet nie pomyśli o tym, aby spędzić wolny czas w teatrze. Jeśli nawet zostanie do niego zaproszony, odpychać może go od teatru trudny język krytyki teatralnej oraz brak możliwości podzielenia się własnym doświadczeniem z innymi widzami. Dlatego tak ważne jest, aby widz po prostu poczuł się bezpiecznie i swobodnie w teatrze ${ }^{22}$.

Agnieszka Graff, która również była obecna w Scenie Roboczej podczas debaty o przyszłości kultury, przytaknęła: „Tak, właśnie chodzi o to, aby słuchać, aby uznać, że doświadczenie widza, jakiekolwiek ono by było, jest ważne”.

Warsztat socjologiczno-teatrologiczny, o którym tu mowa, może budzić wątpliwości wśród badaczy przywiązanych do takiej wersji zogniskowanego wywiadu grupowego, w której moderator pozostaje bierny, spokojnie przysłuchuje się dyskusji między badanymi, ogranicza się do dopytywania o opinię bardziej wstydliwych osób. Można twierdzić, że funkcja edukacyjna warsztatu, o którym tu mowa, mogła mieć znaczący wpływ na przeprowadzane za jego pomocą badania, czyli na funkcję poznawczą przedsięwzięcia. Z definicji warsztat ma charakter dydaktyczny, badania natomiast - poznawczy. Wszystko zależy jednak od tego, jak połączymy dydaktykę z funkcją poznawczą działania.

Przygotowując warsztaty, często rozmawiałem z teatrolożką, profesor Ewą Czaplińską. Wspólnie stwierdziliśmy, że warsztaty będą polegały głównie na oddaniu głosu widzom. W ich trakcie widzowie dyskutowali z sobą, a my zadawaliśmy im pytania. Profesor Czaplińska zwracała uwagę na te elementy przedstawienia, które umykały uwadze laika, w tym mojej. Nie mówiła jednak, jak mają je interpretować

${ }^{21}$ W roku 2013 w teatrze nie było 72,7\% osób, które wzięły udział w badaniu prowadzonym przez zespół, w którym uczestniczył Szlendak. W teatrze nie ma osób najgorzej wykształconych $(92,6 \%)$ i osób z wykształceniem zasadniczo zawodowym $(88,6 \%)$.

${ }^{22}$ Jest to o tyle ważne, że kultura zaczyna dzielić w negatywnym sensie, a nie w pozytywnym, czyli takim, że osoby z niższej pozycji, gdy zaczynają wykonywać te same praktyki kulturowe, co osoby znajdujące się na wyższych pozycjach społecznych, awansują w hierarchii społecznej. Podział na dół i górę przebiega nie poprzez nabywanie nowych kompetencji i ciągnięcia w górę tych, którzy są wyżej, czy, mówiąc inaczej, dzielenie się praktykami kulturowymi z tymi, którzy są niżej, ale na pozostaniu na dole tych, którzy są niżej. 
i za pomocą jakich narzędzi, ale pytała, czy je zauważali, co o nich myślą. Odpowiadała również na pytania widzów, gdy ci dopytywali o kontekst powstania jakiegoś dzieła lub o biografię artysty. Czasami widzowie byli ciekawi interpretacji profesor Czaplińskiej jakiejś sceny lub gestu. Przedstawiała ona własną interpretację dość zachowawczo, słuchając, jaka jest reakcja widzów; zdarzało się, że nie zgadzali się z nią (albo z moją) i proponowali własne odczytanie spektaklu. Inaczej mówiąc, każdy z nas był widzem, wspólnie z sobą dyskutowaliśmy, słuchając siebie nawzajem i nie bojąc się przedstawiać własnej interpretacji. Walor edukacyjny warsztatu nie polegał na przekazywaniu informacji, ale na dyskusji - uczyliśmy się z sobą rozmawiać o teatrze. Zapis tych rozmów stał się dla mnie materiałem badawczym, który poddałem analizie.

\section{Badania jako animacja kulturowa}

Badania kultury, idąc krok dalej, mogą być wręcz formą animacji kultury. Odwołam się w tym miejscu do wspomnianego już projektu „Młodzi i teatr”23. Jednym z podstawowych założeń naszych badań było dotarcie do szerokiego spektrum młodych ludzi z różnych wielkopolskich ośrodków. Dlatego wspólnie oglądaliśmy spektakle i rozmawialiśmy o nich z nastolatkami z bardzo różnych miejscowości - od tych najmniejszych przez miasta średnie (Kalisz, Konin, Piła, Gniezno, Wągrowiec), aż do Poznania, stolicy regionu ${ }^{24}$. Staraliśmy się także uwzględniać to, że rozmówcy mają częstszy lub rzadszy kontakt $\mathrm{z}$ teatrem. Różnice między młodymi ludźmi, które napotkaliśmy, przerosły jednak nasze oczekiwania. Czasami porównywanie poszczególnych grup młodych ludzi było bardzo trudne. Niektórzy licealiści, zwykle ci z mniejszych miast, sprawiali wrażenie osób młodszych, niż wskazywałaby na to ich metryka, podczas gdy inni, najczęściej z większych miejscowości - przypominali dojrzałych studentów. Nie były to zwykle różnice indywidualne, lecz różnice między całymi grupami wywodzącymi się z poszczególnych ośrodków - tych mniej i bardziej peryferyjnych.

Jedną z takich różnic było znaczenie, jakie dla młodych ludzi miał sam udział w badaniu. W przypadku mniejszych ośrodków badanie okazało się odgrywać bardzo ważną rolę, a badacze stali się w pewnym sensie animatorami kultury. Część młodzieży, mieszkająca na obszarach wiejskich lub w bardzo niewielkich miejscowościach, miała pierwszy raz kontakt $\mathrm{z}$ teatrem. W przypadku mniejszych miast młodzi ludzie

${ }^{23}$ Zob. www.badanieteatru.pl [odczyt: 24.02.2020].

${ }^{24}$ W Poznaniu rozmawialiśmy z młodzieżą, zarówno z Poznania, jak i z okolicznych miejscowości, podczas Festiwalu Malta w czerwcu 2013 roku, a z mieszkańcami pozostałych miast i wsi jesienią 2013 roku. W ramach programu „Teatr Polska” Instytutu Teatralnego im. Zbigniewa Raszewskiego w Warszawie odbyły się wówczas we wspomnianych w tekście głównym miejscowościach pokazy spektakli powstałych w dużych ośrodkach (m.in. Warszawie). 
często po raz pierwszy uczestniczyli w spektaklu niebędącym adaptacją lektury lub mieszczańską komedią. W przypadku peryferyjnych miejscowości teatr okazywał się też często jedną z niewielu jakichkolwiek form rozrywki, witaną z entuzjazmem, jako sposób na zabicie nudy, bo, jak powiedziała jedna z osób, „Zwykle to tu się nic nie dzieje”. Licealistka zaś z małego miasta, która wzięła udział w spektaklach i badaniu, powiedziała: „Gdyby nie to, że tutaj byliśmy na tych przedstawieniach to bym czegoś takiego nie szukała w internecie, a tak to coś innego [uśmiech] szukam teraz... tak bezczynnie. Zabijam nudę tym”.

Potrzeba nowych bodźców (a więc innych niż te dobrze znane ze swojej miejscowości) sprawiała, że kilka osób, które przy naszym wsparciu wybrały się z mniejszych miast do Poznania na Festiwal Malta, za równie atrakcyjne uważały udział w wydarzeniach teatralnych i możliwość wizyty w McDonald's. Wyjazd był przez tych licealistów oceniany bardzo dobrze, ponieważ spełnił podstawowy wymóg: stał się jedną z okazji do przełamania codziennej monotonii. Charakter samego spektaklu wydawał się dla wielu z tych osób drugorzędny.

$\mathrm{W}$ badaniach uczestnictwa w kulturze trzeba wziąć więc pod uwagę to, że sam spektakl nie zawsze będzie najważniejszy, że czasami istotne są po prostu nowe bodźce, wyrwanie się z przyjaciółmi z domu. Jak się okazało, badania uczestnictwa w kulturze dla licealistów, których wypowiedzi przywołałem, były formą animacji kultury - badania te stały się częścią ich uczestnictwa w kulturze.

\section{Wspólpraca sztuki i nauki}

Emancypacja, a także pewna forma animacji kultury, może zostać włączona w spektakl teatralny lub dzieło sztuki już na samym początku jego powstawania. Spektakl teatralny, który w swej strukturze zawiera element badawczy bądź po prostu jest badaniem, otwiera nowe możliwości tworzenia teatru. Jest to chyba coś, co bardzo interesuje niektórych twórców teatru: gra realności z fikcją [Pustoła et al. 2019].

W 2018 roku w Instytucie Teatralnym w Warszawie miał premierę spektakl przygotowany w ramach mojego projektu „Moralność milcząca” finansowanego przez Narodowe Centrum Nauki. Do projektu zaprosiłem Wojtka Ziemilskiego, a ten zaprosił Wojtka Pustołę, Seana Palmera i Ulę Hajdukiewicz. Podczas pracy nad spektaklem dyskutowaliśmy o eksperymentach Milgrama, które zostały uznane przez dużą część środowiska naukowego za nieetyczne. Chcieliśmy uniknąć wmanewrowywania widza w sytuację bez wyjścia [O czym mówi Sean? 2019].

Jakim zaskoczeniem okazało się dla mnie to, że kilka osób po obejrzeniu spektaklu powiedziało mi: Ten spektakl powinien jeździć po liceach, ponieważ mógłby uczyć młodzież współpracy i radzenia sobie z dylematami oraz uświadamiałby im, że każdy z nas jest odpowiedzialny za swoje decyzje. My, twórcy spektaklu, rozmawiamy o Milgramie, a widzowie mówią nam, że spektakl spełnia funkcje edukacyjne. 
Projekt, o którym mowa, dotyczy moralności, a jego geneza pochodzi z prostej obserwacji. Od kilkudziesięciu lat badanie moralności stało się popularne, przede wszystkim wśród psychologów społecznych i ewolucyjnych czy kognitywistów, którzy w swych badaniach wykorzystują tak zwane dylematy moralne, czyli hipotetyczne historyjki, które badany czyta lub ogląda ich wizualizację (zob. Green, Haidt 2002; Abend 2013; Brockman 2013; Haidt 2014; por. też The Moral Machine ${ }^{25}$; The Moral Sense Test $\left.{ }^{26}\right)$. Problemem w tego typu badaniach jest to, że badani wyobrażają sobie sytuację, w której muszą dokonać wyboru, na przykład czy zostawić pędzący tramwaj na torowisku, a wówczas zabije przechodnia, czy skierować go na bocznicę, ale wtedy zabije pięciu robotników pracujących na torach. Po drugie, badania te dotyczą jednostek, a nie mechanizmów społecznych, które wpływają na podejmowanie decyzji i na to, jak myślimy w danej chwili o moralności. Aby skonstruować sytuację społeczną, w której uczestnicy realnie wezmą udział, skierowałem się w stronę sztuki, w stronę teatru.

Nie ma tu miejsca, aby dokładnie opisać skonstruowaną przez nas metodę badawczą. Zainteresowanego Czytelnika odsyłam do „Przeglądu Socjologii Jakościowej", gdzie zamieszony został zapis dyskusji o spektaklu i o tym, w jakim zakresie sztuka może być metodą badawczą [O czym mówi Sean? 2019]. Krótko zatem. Spektakl, który zatytułowaliśmy Sean powie parę słów o sobie, polegał na tym, że sześcioro osób miało wybierać zadania dla performera spośród dostępnych opcji. Rund było czternaście, opcji zwykle trzy. Po ostatnim pytaniu wchodziłem na scenę i wraz z widzami dyskutowaliśmy o ich emocjach, uczuciach, doświadczeniach, interpretacjach własnego zachowania. Następnie widzowie wychodzili z sali teatralnej i spotykali się na korytarzu z performerem oraz twórcami spektaklu - mogli z nim porozmawiać, zadać pytanie w bardzo swobodnej atmosferze „na korytarzu”, co też chętnie czynili. Na poziomie produkcji dzieła artystycznego można wbudować więc element badawczy - rozmowę albo dyskusję, niezobowiązujące i intymne spotkanie $\mathrm{w}$ małym gronie $\mathrm{z}$ twórcami dzieła ${ }^{27}$.

\section{Różnorodne reģulatory zachowan}

Na sposób uczestnictwa w kulturze wpływ mają nie tylko dzieła sztuki. W latach 2011-2013 rozdaliśmy uczestnikom Festiwalu Malta minikamerę wideo Flip - jest ona łatwa w obsłudze i niewielka ${ }^{28}$. Miała posłużyć im do dokumentowania zdarzeń,

${ }^{25}$ Zob. http://moralmachine.mit.edu/ [odczyt: 24.02.2020].

${ }^{26}$ Zob. http://www.moralsensetest.com/ [odczyt: 24.02.2020].

27 Taką dyskusję może zaproponować również instytucja, choć trzeba zaznaczyć, że mówimy tu o zupełnie innym doświadczeniu niż typowe spotkanie z artystami, na którym zostaje zwykle garstka osób.

${ }^{28}$ Panel składa się z czerwonego guzika nagrywania i przycisku z symbolami strzałek (przeglądanie materiału) oraz „+” i „-” ( zoom in i zoom out oraz regulacja głośności). Niewielkie wymiary kamery sprawiają, że łatwo mieści się w torbie na ramię bądź w kieszeni spodni. 
w których uczestniczyli, rozmów, jakie toczyli, ukazania siebie samych oraz innych w kontekście festiwalu. Interesowało nas to, co pozainstytucjonalne ${ }^{29}$, dlatego autorzy dzienników co dwie lub trzy godziny rejestrowali to, co dzieje się wokół nich, i co robią w danym momencie (nazwaliśmy te filmy „notatkami uporządkowanymi”). Dodatkowo poprosiliśmy ich, aby wykazali się inwencją i filmowali to, co uważali za ciekawe, ważne, interesujące (tzw. „notatki impresje”).

Większość „dziennikowców” swobodnie łączyła „notatki uporządkowane” $\mathrm{z}$ „notatkami impresjami”, traktując instrukcję do tworzenia dziennika wizualnego jako zestaw raczej myśli przewodnich niż sztywnych reguł. Łącznie badani nakręcili 1071 filmów (w tym 26 filmów z wywiadów) nakręconych przez 16 osób (12 kobiet i 4 mężczyzn ${ }^{30}$ ) biorących udział w badaniach w okresie 2011-2013 ${ }^{31}$. Filmy trwały od kilku sekund do kilku minut. Swoboda realizacyjna z pewnością sprzyjała uzyskaniu ciekawego materiału do analizy praktyk uczestnictwa, ale nie pozwoliła na zaprezentowanie sumarycznych podsumowań. Założyliśmy, że możliwe jest traktowanie materiałów z wszystkich lat realizacji projektu, jako ekwiwalentnych, ponieważ szczegółowe zalecenia instrukcji realizacji dziennika wizualnego oraz w dyspozycji wywiadu pogłębionego z osobami realizującymi dzienniki na przestrzeni lat nie zostały zmienione (wyjątek stanowi, wspominany wcześniej, większy nacisk na regularne wykonywanie „notatek uporządkowanych” w 2013 roku) ${ }^{32}$.

Zgromadzony materiał nie pozwala na dokonanie jednoznacznych klasyfikacji (na przykład czy kobiety kręcą więcej/częściej/dłużej, niż mężczyźni, czy też odwrotnie? czy intensyfikacja liczby spektakli w ramach festiwalu wpływała na zwiększenie liczby nagrań w poszczególne dni tygodnia? itd.), w związku z tym potraktowaliśmy go zbiorczo jako zestaw świadectw różnych form uczestniczenia w festiwalu. Każdy z tych filmów to zapis współtworzenia doświadczenia widzów przez Festiwal Malta przemian ich codziennych rutyny i nawyków - i vice versa, współtworzenia festiwalu przez jego uczestników. Niekiedy to także krótkometrażowe dokumenty na temat festiwalowego otoczenia, osób postronnych, przemian miasta, zapis indywidualnych impresji i skojarzeń, na których uwiecznienie pozwoliła kamera.

Z dzienników wizualnych wynika, że bodźcami, które organizują uczestnictwo w kulturze instytucjonalnej, w festiwalu, są również te rzeczy, na które zwykle

${ }^{29}$ Z badań prowadzonych w ostatniej dekadzie dowiadujemy się, że wiele Polek i Polaków nie czuje się zobowiązanych do uczestnictwa w kulturze instytucjonalnej, ponieważ ważniejsze są dla nich relacje społeczne, które organizowane są w zupełnie innym polu [zob. Drozdowski et al. 2014].

${ }^{30}$ Różnica ta może być tylko konsekwencją zastosowanej metody doboru badanych, który odbywał się w gronie „znajomych” oraz „dalszych znajomych”, na zasadzie poszukiwania „,chętnych / zainteresowanych"; może to też świadczyć o tym, że w Festiwalu Malta uczestniczy więcej kobiet niż mężczyzn.

${ }^{31}$ W 2011 roku zrealizowanych zostało 5 dzienników wizualnych, w roku 2012 - 7, a w 2013 - 4. Na zbiór filmów nakręconych w ramach dzienników wizualnych z 2011 roku złożyło się 357 filmów, w roku 2012 - 516, a w 2013 - 198 filmów.

${ }^{32}$ Wszystkie filmy związane z dziennikami wizualnymi są do odnalezienia na powiązanym z projektem profilem w serwisie Vimeo (http://vimeo.com/user9670919/videos [odczyt: 24.02.2020]). 
w badaniach nie zwraca się uwagi: wylegiwanie się na plaży i relaksowanie przed wysiłkiem intelektualnym w teatrze; picie wina przez studentów, którzy następnie wybiorą się na koncert w ramach Malty, na opuszczonym pod wieczór ryneczku; rodzinne rozmowy w sobotni poranek w ogrodzie, także o spektaklach, które zobaczyło się poprzedniego dnia; jedzenie obiadu z przyjaciółką w przelocie między klubem festiwalowym a wydarzeniem artystycznym; kolejka do toalet przenośnych ToiToi w ramach dużego koncertu muzycznego, podczas której nawiązywane są swobodne rozmowy z kolejkowiczami.

W badaniach, w których użyliśmy dzienników wizualnych, nie chodzi o podkreślenie, że praktykami kulturowymi nie są dziś wyłącznie takie praktyki, jak uczęszczanie do instytucji kultury czy odbiór dóbr kultury, lecz są nimi także, jak pisał Tomasz Szlendak i: „umiejętności skutecznego podrywu, know-how w zakresie obdzierania królika ze skóry czy wysoka sprawność w przygotowywania sernika na zimno" [2017: 407] czy, jak dodaje Fatyga: „sposoby rodzenia w wodzie” [zob. Drozdowski et al. 2014: 407]. Dzienniki wizualne miały nie tylko poszerzyć zakres praktyk kulturalnych dostępnych badaczowi, lecz także pomóc mu znaleźć inne regulatory zachowań. W naukach społecznych zbyt często skupiamy się na badaniu wartości i praktyk jako czynników regulujących zachowanie ludzi. W tym kontekście bardzo trafne wydają się słowa Krajewskiego: „Być może warto by było znaleźć jakieś narzędzia, które sprawdzają miejsce wartości jako kategorii w porządku działania i weryfikują, czy ta pozycja wartości jako kategorii jest stała" [Drozdowski et al.: 420]. Sposób uczestniczenia w kulturze nie zależy tylko od wyznawanych, explicite bądź implicite, wartości, lecz jest regulowany przez wiele czynników (np. naśladownictwo, reakcja w tłumie, plotkowanie). Jeśli chcemy zrozumieć sposoby uczestnictwa ludzi w kulturze, musimy uwzględnić fakt, że istnieje wiele regulatorów zachowań.

Badania, które nie skupiają się wyłącznie na dziele sztuki albo instytucji kultury, mają większą szansę dostrzec, że uczestnictwo w kulturze jest wieloaspektowe i nie da się go zredukować jedynie do wypowiedzi, opinii czy poglądów widzów. Stosując takie narzędzia badawcze, jak dzienniki wizualne, aparaty fotograficzne, aplikacje mobilne można zidentyfikować niedyskursywne regulatory zachowań uczestników kultury. Dodatkową funkcją takich narzędzi badawczych jest ich potencja do włączenia ludzi w kulturę. Na przykład osoby, które filmowały swoje uczestnictwo podczas Festiwalu Malta, zaczęly bawić się kamerą Flip, szukając dla niej nowych funkcji - byli twórczy [Rapior 2016]. Forma dziennika, a więc: (a) długość filmów; (b) ich częstotliwość; (c) kadr; (d) rodzaj komentarza słownego (temat, sytuacja w jakiej został wypowiedziany, etc.) stanowią cenną informację świadczącą o sposobie pośredniczenia kamery wideo w sposobie uczestnictwa w festiwalu, lecz - co równie ważne - o formie uczestnictwa w kulturze osób biorących udział w badaniu. Mówiąc inaczej, kamera stała się elementem ich uczestnictwa, a my, badacze, mogliśmy zaobserwować, jak kamera to uczestnictwo kształtuje. 


\section{Ideolog̣ia}

Nauka powinna być wolna od wartościowania. Jest to powszechny pogląd w świecie naukowym - dowody, a nie ideologia lub poglądy polityczne, mają uzasadniać konkluzję badań. Co więcej, teorie naukowe nie stanowią własności ich autorów, lecz należą do społeczności uczonych [Markovsky, Dilks 2013]. Jednakże, po pierwsze, jak przypomina Leszek Kołakowski, „przekonanie, że opis i analiza uwolniona od normatywnych przesądów są więcej warte niż duch wyższości lub fanatyzmu" [2006: 17], jest sądem wartościującym. Bezstronność i cenienie wyżej faktów od fikcji oraz krytycyzm nie są „neutralnymi” ideami wolnymi od założeń normatywnych. Po drugie, badacz, wybierając przedmiot badania, kieruje się przekonaniem, że jego badanie jest potrzebne i ważne. Badacze nie wybierają tematów przypadkowo, zwykle badają to, co ich interesuje. Feministka przyglądając się ekonomii, będzie chciała zbadać, na przykład, nierówności w płacach między mężczyznami a kobietami. Nie oznacza to, że jej badania będą „spaczone”; nie będą dopóty, dopóki będzie się ona kierowała w trakcie procesu badawczego bezstronnością. Wybór przez feministkę (lub feministę) przedmiotu badań jest jednak wartościujący - to ona (lub on), z własnej perspektywy, uzasadnia przed innymi, że badania, które chce prowadzić, są warte finansowania, poświęcenia czasu albo zasobów instytucjonalnych.

Badaczka lub badacz kultury, wybierając na swój przedmiot badania nie teatr albo galerię sztuki, lecz ogród społecznościowy albo produkcję miodu, również kieruje się wartościami - uznaniem, że takie praktyki, jak ogrodnictwo albo pszczelarstwo, są kulturotwórcze i ważne. W tym miejscu warto przywołać słowa Maxa Webera [2011]. Podkreślał on, że badacz podejmuje dwa kroki: (1) pierwszy krok, to wybór przedmiotu badania, (2) drugi krok - proces badawczy. Weber twierdził, że pierwszy krok będzie zawsze wartościujący. Wybór tego, co chcemy badać, zależy od tego, co jest dla badacza ważne. Drugi krok natomiast powinien być wolny od wartości w tym sensie, że badacz w procesie badawczym powinien się kierować bezstronnością.

Antropolog francuski Philippe Descola [2013] podkreśla, że wartościowanie przy wyborze tematu jest wręcz niezbędną częścią każdego rzetelnie przeprowadzonego badania. Pisał:

W przeciwieństwie do naszych kolegów, którzy specjalizują się w fizyce kwantowej lub embriogenezie, i są zainteresowani badanymi zjawiskami, ponieważ wierzą, że mogą je wyjaśnić, naukowcy społeczni są zwykle proszeni o wyjaśnienie zjawisk, które po raz pierwszy zasugerowali im inni - na przykład media lub lobbyści - a które niechętnie traktują za uzasadnione tematy badawcze [Descola 2013].

Każdy badacz powinien mieć pełną autonomię w wyborze tematu - to ona lub on powinien wyznaczyć uzasadnione tematy badawcze. W każde badanie wbudowane 
są założenia normatywne. Badania powinny ukazywać własną ideologiczność, co oznacza, iż rolą badacza jest szczegółowe opisanie metodologii badań, pytań badawczych i powodów, dla których stawia te pytania.

Zidentyfikowanie zmian w kulturze i poszerzenia pola kultury, poświęcenie mu czasu oraz zrozumienie i wyjaśnienie jak i dlaczego ludzie uczestniczą w kulturze, obnaża, mówiąc za Krajewskim, „jak bardzo zideologizowany jest system instytucji kultury, jak bardzo on reprodukuje nierówności, jak bardzo wyklucza pewne kategorie osób" [za: Drozdowski et al. 2014: 4]. Rzetelne badania podważają założenia, które ludzie przyjmują z racji swego członkostwa w szerszej społeczności [Baert, da Silva 2013]. Rzetelne badania często podają w wątpliwość założenia, którymi kierujemy się w codziennym życiu, w tworzeniu polityki czy badaniach. Badania same w sobie jednak nie są propozycją polityki kulturalnej. Badania mogą wszak posłużyć za pomoc w publicznych dyskusjach i negocjowaniu, jakie ważne cele społeczne chcemy za pomocą polityk kulturalnych realizować. Nie ma bowiem żadnego neutralnego algorytmu, który byłby wcześniejszy od rozmowy między obywatelami.

\section{Etyka instytucjonalna}

Ważnym elementem badań kultury instytucjonalnej powinna być etyka instytucjonalna. Akcja \#MeToo [Kwaśniewska 2019], coraz większe znaczenie krytyki instytucjonalnej [Keil 2017], kwestia finansowania teatrów, konieczność obecności związków zawodowych w instytucjach kultury, proces projektyzacji instytucji kultury [Ćwikła 2016], sposób powstawania dzieł artystycznych - wszystkie te zjawiska, akcje, działania i pytania stają się dziś coraz ważniejsze. Aktor Dobromir Dymecki powiedział: „Trudno mi zachwycać się dobrym spektaklem, jeśli wiem, że podczas pracy nad nim ludzie zostali nadużyci, źle potraktowani czy zrobieni w bambuko" [za: Rapior 2019: 96]. Etyka powinna być zarówno przedmiotem badawczym dla badaczy kultury, jak i tematem debaty - badania kultury mogą do niej wiele wnieść. Mimo to kwestia etyki instytucjonalnej jest jednym z niedowartościowanych tematów badań kultury.

\section{lakończenie?}

W artykule przedstawiłem propozycję podejścia badawczego, która wpisuje się w (i z niej wynika) poszerzoną koncepcję kultury. Poszerzone metody badań kultury powinny uwzględniać, że:

1. badanie jest interakcją;

2. badania powinny wzmacniać emancypację i proces demokratyzacji życia społecznego;

3. proces badawczy jest formą animacji kultury; 
4. warto współpracować z artystami (a także aktywistami, obywatelami, widzami, reprezentantami instytucji kultury) podczas tworzenia badań;

5. jest wiele regulatorów naszych zachowań, nie tylko najczęściej badane przez nauki społeczne wartości i praktyki;

6. w każde badanie wpisane są pewne założenia i powinny one zostać odkryte i omówione publicznie;

7. ważnym tematem jest etyka.

Nie ma tu miejsca, aby każdy z powyższych punktów krytycznie omówić, dlatego na zakończenie zadam pytanie: Do jakiego stopnia metoda badawcza, która uwzględnia wszystkie powyższe punkty, opisuje rzeczywistość społeczną, a do jakiego również pomaga ją stwarzać? Pytanie to od zawsze było ważne w socjologii, która od zarania stała na rozdrożu między naukami przyrodniczymi a naukami humanistycznymi. Jeśli uznamy, że metody w jakiejś mierze stwarzają rzeczywistość społeczną, pytanie, w jakiej i czy w ogóle, pozostawiam na razie otwarte - to każdy badacz przystępując do badań, musi znaleźć odpowiedź nie tylko na pytania związane z rzetelnością, bezstronnością i trafnością jego hipotez i procesu badawczego, ale także jakie realia społeczne chce wspierać i tworzyć.

$\mathrm{W}$ artykule przedstawiłem siedem kwestii, które badacz odpowiadający twierdząco na pytanie „Czy metody stwarzają rzeczywistość społeczną?”, powinien wziąć pod uwagę przy projektowaniu badań. Jeśli chcemy odpowiedzialnie badać kulturę, musimy wiedzieć, jak przygotować nasze badania. Ta uwaga kończy mój artykuł, ale nie powinna zamykać dyskusji na temat metod badawczych. Przeciwnie, powinna ją otwierać.

\section{Biblioggrafia}

Abend G. (2013), What the Science of Morality Doesn't Say about Morality, „Philosophy of the Social Sciences", Vol. 2, No. 43, s. 157-200.

Allard A. (2018), Non-replicable: The Methodological Crisis in Experimental Science, „Books \& Ideas", 28.05.2018, https://booksandideas.net/Non-replicable.html [odczyt: 1.06.2019]. Atkinson P., Sliverman D. (1997), Kundera's Immortality: The Interview Society and the Invention of the Self, „Qualitative Inquiry”, Vol. 3, No. 3, s. 304-325.

Bachórz A., Ciechorska-Kulesza K., Czarnecki S., Grabowska M., Knera J., Michałowski L., Stachura K., Szultka S., Obracht-Prondzyński C., Zbieranek P. (2014), Punkty styczne. Między kultura a praktyką (nie)uczestnictwa, Gdańsk: Instytut Kultury Miejskiej.

Baert P., Silva F.C. da (2013), Teorie społeczne w XX wieku i dzisiaj, tłum. S. Burdziej, Kraków: Nomos.

Bennett T. (2005), Culture, [w:] T. Bennett, L. Grossberg, M. Morris (red.), New Keywords: A Revised Vocabulary of Culture and Society, Hoboken, NJ- Oxford-Chichester: Wiley-Blackwell. 
Blumer H. (2006), Implikacje socjologiczne myśli George’a Herberta Meada, tłum. D. Nikls, [w:] A. Jasińska-Kania, L.M. Nijakowski, J. Szacki, M. Ziółkowski (red.), Współczesne teorie socjologiczne, Warszawa: Wydawnictwo Naukowe Scholar, s. 262-271.

Brinkmann S. (2016), Methodological Breaching Experiments: Steps Toward Theorizing the Qualitative Interview, „Culture \& Psychology”, Vol. 22, No. 4, s. 520-533.

Brockman J. (2013), Thinking: The New Science of Decision Making, Problem-Solving, and Prediction, New York-London-Toronto et al.: Harper Perennia.

Chajbos K., Rapior W., Szymańska-Palaczyk A. (2014), Widz obrażony? O reakcjach na wybrane spektakle Malta Festival Poznań 2014, Poznań: Fundacja Malta.

Chambers Ch. (2017), The Seven Deadly Sins of Psychology: A Manifesto for Reforming the Culture of Scientific Practice, Princeton: Princeton University Press.

Collins H. (2018), Czy wszyscy jesteśmy ekspertami?, tłum. E. Bińczyk, J. Grygieńć, Warszawa: Wydawnictwo Naukowe PWN.

Czapliński P. (2017), Dystynkcje i wiązania. Historia konfliktu dwóch kultur prawomocnych, [w:] C. Obracht-Prondzyński, P. Zbieranek (red.), Pomorskie poszerzenie pola kultury. Dylematy, konteksty, działania, Gdańsk: Nadbałtyckie Centrum Kultury, s. 77-92.

Ćwikła M. (2016), Projekt to jest projekt. Specyfika zarządzania projektami kulturalnymi na przykładzie tworzenia koprodukcji teatralnych, Kraków: Attyka.

Descola P. (2013), In Praise of Social Sciences, „Books \& Ideas”, 21.10.2013, https://booksandideas.net/In-Praise-of-Social-Sciences.html [odczyt: 1.06.2019].

Doliński D., Grzyb T. (2017), Posłuszni do bólu, Sopot: Smak Słowa.

Drozdowski R. et al. (2014), Praktyki kulturalne Polaków, Toruń: Wydawnictwo Naukowe UMK.

Goffman E. (2006), Rytuał interakcyjny, tłum. A. Szulżycka, Warszawa: Wydawnictwo Naukowe PWN.

Goffman E. (2008), Zachowanie w miejscach publicznych. O społecznej organizacji zgromadzeń, tłum. O. Siara, Warszawa: Wydawnictwo Naukowe PWN.

Greene J., Haidt J. (2002), How (and Where) Does Moral Judgment Work?, „Trends in Cognitive Sciences", Vol. 6, s. 517-523.

Haidt J. (2014), Prawy umyst. Dlaczego dobrych ludzi dzieli religia i polityka?, tłum. A. Nowak-Młynikowska, Sopot: Smak Słowa.

Haslam A.S., Reicher S.D. (2012), Contesting the „Nature” of Conformity: What Milgram and Zimbardo's Studies Really Show, „PLOS Biology”, Vol. 10, No. 11, https://journals.plos.org/ plosbiology/article?id=10.1371/journal.pbio.1001426 [odczyt: 1.06.2019].

Kaufmann J.-C. (2010), Wywiad rozumiejacy, tłum. A. Kapciak, Warszawa: Oficyna Naukowa.

Keil M. (2017), Do kogo należy teatr? O tym, do czego może nam się dzisiaj przydać krytyka instytucjonalna, „Dialog”, nr 11, http://www.dialog-pismo.pl/w-numerach/do-kogo-nalezy-teatr-o-tym-do-czego-moze-nam-sie-dzisiaj-przydac-krytyka-instytucjonalna [odczyt: 1.06.2019].

Kołakowski L. (2006), Czy diabeł może być zbawiony i 27 innych kazań, Kraków: Znak. 
Kosiński D., Rapior W. (2018), Wiedza z działania, wiedza w działaniu. O relacjach sztuki i na$u k i$, „Czas Kultury” http://czaskultury.pl/artykuly/wiedza-z-dzialania-wiedza-w-dzialaniu o-relacjach-sztuki-i-nauki/ [odczyt: 1.06.2019].

Krajewski M. (2013), W kierunku relacyjnej koncepcji uczestnictwa w kulturze, „Kultura i Społeczeństwo", nr 1, s. 29-67.

Krajewski M. (2017), „Ja poszerzam”, „Ty poszerzasz”... Poszerzona koncepcja kultury i wynikające stąd nieporozumienia, [w:] C. Obracht-Prondzyński, P. Zbieranek (red.), Pomorskie poszerzenie pola kultury. Dylematy, konteksty, działania, Gdańsk: Nadbałtyckie Centrum Kultury, s. 29-42.

Kwaśniewska M. (2019), Między wolnościq a manipulacją. Sytuacja aktorek i aktorów w „Factory 2”, „Didaskalia. Gazeta Teatralna”, nr 150, s. 2-9.

Law J. (2004), After Method: Mess in Social Science Research, New York: Routledge.

Lury C., Wakeford N. (2012), Inventive Methods: The Happening of the Social, New York: Routledge. Mateja-Jaworska B. et al. (2013), Młodzi i teatr. Szanse i bariery na przykładzie Wielkopolski. Raport oraz opracowania powstałe na bazie projektu zrealizowanego w 2013 roku ze środków Ministerstwa Kultury i Dziedzictwa Narodowego w programie „Obserwatorium kultury", Poznań: Fundacja Malta.

Markovsky B., Dilks L.M. (2013), Nauka, pseudonauka i zdrowy rozsądek, tłum. K. Tomanek, K. Wysieńska, [w:] J. Heidtman, K. Wysieńska (red.), Procesy grupowe. Perspektywa socjologiczna, Warszawa: Wydawnictwo Naukowe Scholar, s. 19-62.

O czym mówi Sean? (2019), Zapis panelu dyskusyjnego o sztuce, nauce i etyce, „Przegląd Socjologii Jakościowej”, t. 15, nr 2, s. 246-263, www.przegladsocjologiijakosciowej.org [odczyt: 1.06.2019].

Obracht-Prondzyński C., Zbieranek P. red. (2017), Pomorskie poszerzenie pola kultury. Dylematy, konteksty, działania, Gdańsk: Nadbałtyckie Centrum Kultury.

Perry G. (2013), Behind the Shock Machine: The Untold Story of the Notorious Milgram Psychology Experiments, New York: The New Press.

Pustoła W. et al. (2019), Kiedy teatr nie tylko gra i/ale bada, [w:] W. Rapior (red.), Bezkarnie. Etyka w teatrze, Poznań: Stowarzyszenie Scena Robocza, Stowarzyszenie Czasu Kultury, s. 169-182.

Rakowski T. red. (2015), Etnografia / Animacja / Sztuka. Nierozpoznane wymiary rozwoju kulturalnego, Warszawa: Narodowe Centrum Kultury.

Rapior W. (2016), Jak budowana jest przestrzeń prywatna we wspótczesnym mieście. Analiza dzienników wizualnych, „Kultura i Społeczeństwo”, nr 2, s. 145-160.

Rapior W. red. (2019), Bezkarnie. Etyka w teatrze, Poznań: Stowarzyszenie Scena Robocza, Stowarzyszenie Czasu Kultury.

Rapior W., Skorupska P. (2015), „...żeby spektakl dawał do myślenia”? Podsumowanie spotkań $z$ widzami w wieku 16-19 lat podczas Malta Festival Poznań 2015, Poznań: Fundacja Malta. Sikora S. red. (2015), Oddolne tworzenie kultury. Perspektywa antropologiczna, Warszawa: Instytut Etnologii i Antropologii Kulturowej Uniwersytetu Warszawskiego. 
Skórzyńska A. (2017), Miasto i praxis. Ćwiczenia z kulturowych badań angażujących, Warszawa: Instytut Badań Literackich PAN.

Sormani P., Carbone G., Gisler P. red. (2018), Practicing Art / Science: Experiments in an Emerging Field, London-New York: Routledge.

Szlendak T., Olechnicki K. (2017), Nowe praktyki kulturowe Polaków. Megaceremoniały i subświaty, Warszawa: Wydawnictwo Naukowe PWN.

Weber M. (2011), Racjonalność, władza, odczarowywanie, tłum. M. Holona, Poznań: Wydawnictwo Poznańskie.

Williams R. (1985), Keywords: A Vocabulary of Culture and Society, Revised edition, New York: Oxford University Press. 